\title{
The Analysis of Learning Objectives in Iranian Junior High School English Text books based on Bloom's Revised Taxonomy
}

\author{
Ayoub Rahpeyma \\ Department of English, College of Humanity Science, Bandar Abbas Branch, Islamic Azad University, Bandar Abbas, Iran \\ E-mail: j.rahpeyma@gmail.com
}

Ali Khoshnood (Corresponding author)

Faculty of Linguistics and Foreign Languages, Payame Noor University, PO Box: 19395-3697 Tehran, I.R. Iran

E-mail: thisali42@yahoo.com

Received: 15-02- 2015

Accepted: 10-04-2015

Published: 30-04-2015

doi:10.7575/aiac.ijels.v.3n.2p.44

URL: http://dx.doi.org/10.7575/aiac.ijels.v.3n.2p.44

\begin{abstract}
This study was carried out to evaluate the Iranian junior high school English text books according to learning objectives of Bloom's Revised Taxonomy (2001) to find which learning levels of Bloom's Revised Taxonomy were more common in these text books. The primary data in this study came from the newly published English text book, English for Schools series consisting of two three-volume series named Prospect 1, 2 and English book grade three named Right Path to English. Therefore, the data sources were junior high school English text books contents. This study is important as these course books are the first English text books that have been prescribed for Iranian junior high school students to study from 2014. To fulfill the purpose of this study, the contents of junior high school English text books were codified by a coding scheme of BRT. The data were then analyzed; at the first step the frequency and percentage of occurrence of different learning objectives from each book was separately considered and then the average of the whole books were calculated. Results from the codification of 439 tasks and exercises indicated that in three grades, the first three low levels in BRT were the most prevalent than higher learning levels in Iranian junior high school English text books. In addition an important difference was found among the text books in their inclusion of different levels of learning objectives of two dimensions of BRT (knowledge and cognitive). This study can provide useful information for text book development, curriculum writers, and syllabus designers to boost English learning in the EFL setting of Iran.
\end{abstract}

Keywords: Bloom's Revised Taxonomy, Junior high school English text books, Text book

\section{Introduction}

English as the international language plays a crucial role in worldwide interactions and relationships. For many countries, English language education policy has become a major concern of their officials. However, educational policy of these authorities has influenced their communities in ways that are often controversial (Khajavi \& Abbasian, 2011). According to Chang (2006) English has been the prevailing foreign language in the curricula of educational institutions and in foreign language learning. Many countries welcome instruction of English language in order to be actively engaged in the international activities. Thus, the major concerns of such countries have been always to find the ways to extend teaching English language in an effective manner.

There are various factors in teaching and learning English process such as teachers, students, schools facilities and infrastructures. But English text books play one of the most crucial roles in teaching/ learning process. As Hutchinson and Torres (1994) stated, the text book has a very important and a positive role to play in teaching and learning English. They also argued that text books contain the necessary input for classroom lessons through different activities. The prescribed and taught text books are usually evaluated in order to examine their effectiveness. Cunningsworth (1995) and Ellis (1997) have argued that there are three different types of material evaluation. They further continued that the most common form is the predictive or pre-use evaluation that is designed to examine the future or potential performance of a text book. The next type of text book evaluation is in-use evaluation designed to examine material that is currently being used and the retrospective or post-use evaluation of a text book that has been used in some respective institutions.

This study employs the theoretical basis of BRT which has been originally emerged from Bloom's Original Taxonomy in (2001) to carry out the research. The revised version comprises some significant changes which were occurred in three broad categories: (a) terminology, (b) structure, and (c) emphasis. These changes in terminology between the two versions are the most obvious difference and can cause the most confusion. Basically, Bloom's six major categories were changed from "noun to verb forms." It was due to the fact that the authors defined cognition as thinking and since thinking is an active process, they preferred verbs because they believe that verbs can describe the action involve in thinking in a better way. In addition, the lowest level of the original, knowledge was renamed and became Remember 
because knowledge is said to be the product of thinking not one type of thinking. Finally, comprehension and synthesis are also renamed as understanding and creating. Additionally, the authors rearranged two of the subcategories in the cognitive process since they wanted to arrange them in the order of increased difficulty. Consequently, they exchanged the order of synthesis which is "create" in the new taxonomy and evaluation which is evaluate in the new taxonomy because they supposed that creative thinking is more difficult than critical thinking. They accept it as true that you can be critical without necessarily being creative, but creative production often necessitates critical thinking. So, in the new taxonomy creating is shown to be more complex than evaluating. In an effort to minimize the confusion, comparison images appear in the following figure 1 .

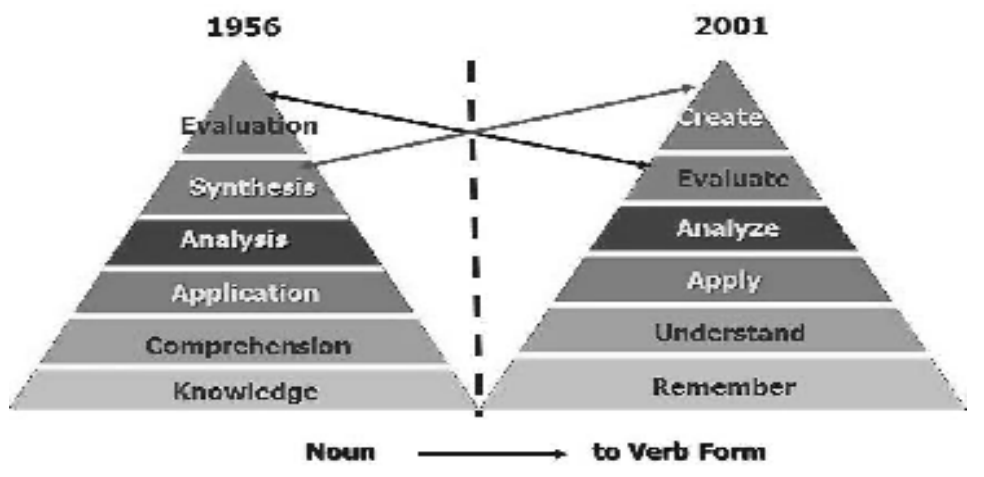

Figure1. Terminology changes between Bloom's and BRT. Adopted from (Anderson \& Krathwohl, 2001)

\section{Structural Changes}

Structural changes seem dramatic at first, yet are quite logical when they are closely examined. Bloom's original cognitive taxonomy was a one-dimensional form. With the addition of products, the Revised Bloom's Taxonomy takes the form of a two-dimensional table. One of the dimensions identifies the Knowledge Dimension (or the kind of knowledge to be learned) while the second identifies the Cognitive Process Dimension (or the process used to learn).

Table 1. The Bloom's Revised Taxonomy grid from Oregon State University

\begin{tabular}{|c|c|c|c|c|c|c|}
\hline \multicolumn{2}{|c|}{ TRT } \\
\hline \multirow{2}{*}{ The Knowledge Dimension } & \multicolumn{5}{|c|}{ The Cognitive Process Dimension } \\
\cline { 2 - 7 } & Remember & Understand & Apply & Analyze & Evaluate & Create \\
\hline Factual Knowledge & & & & & & \\
\hline Conceptual Knowledge & & & & & & \\
\hline Procedural Knowledge & & & & & & \\
\hline Meta-Cognitive Knowledge & & & & & & \\
\hline
\end{tabular}

The Knowledge Dimension on the left side is composed of four levels that are defined as Factual, Conceptual, Procedural, and Meta-Cognitive. The Cognitive Process Dimension across the top of the grid consists of six levels that are defined as Remember, Understand, Apply, Analyze, Evaluate, and Create. The first three of these levels were identified in the original work, but rarely discussed or introduced when initially discussing its uses for the taxonomy. Metacognition was added in the revised version.

- Factual Knowledge: comprises the discrete facts and basic elements that experts use when communicating about their discipline, understanding it, and organizing it systematically.

- Conceptual Knowledge: the interrelationships among the basic elements within a larger structure that enable them to function together.

- Procedural Knowledge: includes criteria which tell when to use various procedures and reflects knowledge of different processes.

- Metacognitive Knowledge: is awareness of and knowledge about one's own thinking. 
The Cognitive Process Dimension levels are also subdivided into the number of sectors in each level ranging from a low of three to a high of eight categories.

- Remember: The learner is able to recall, restate and remember learned information.

- Understand: The learner seizes the meaning of information by interpreting and translating what has been learned.

- Apply: The learner makes use of information in a new situation from the one in which it was learned.

- Analyze: The learner breaks the learned information into its parts to understand how the parts relate to one another and to an overall structure or purpose through differentiating, organizing, and attributing.

- Evaluate: The learner makes decision based on in-depth reflection, criticism and assessment.

- Create: The learner creates new ideas and information using what has been previously learned.

\section{Changes in Emphasis}

Emphasis is the third and final category of changes. Bloom himself recognized that the taxonomy was being "unexpectedly" used by countless groups never considered an audience for the original publication. The revised version of the taxonomy is intended for a much broader audience. Emphasis is placed upon its use as a "more authentic tool for curriculum planning, instructional delivery and assessment" (Oz-Teacher Net, 2001)

\section{Text book Evaluation in Iran}

There have been several studies about the evaluation of text books in Iran. Yarmohammadi (2002) evaluated the senior high school text books based on a revised version of Tucker's model. He came to the conclusion that these text books suffer from a lot of shortcomings: 1. They are not authentic; 2. English and Persian names are used interchangeably; and 3. Oral skills are ignored. At the end, he proposes some suggestions to tackle the shortcomings. Amalsaleh (2004) examined the representation of social factors in three types of text books, including junior and senior high school text books, based on Van Leeuwen's model (1996). According to the results, generally, the text books demonstrated a deferential representation of social factors that tended to portray female as performers belonging to a home context and having limited job opportunities in society. In particular, junior and senior high school text books tended to shape normative views of gender and class relations in which a middle-class urban male was considered to be the norm. Jahangard (2008) examined 10 checklists proposed by different authors and selected some features which were common to the most of these checklists and introduced a framework. The items include explicit objectives in the layout and introduction that are implemented in materials, good vocabulary explanation and practice, educationally and socially acceptable approaches, periodic reviews and test sections, appropriate visual materials, interesting topics and tasks, clear instructions, clear attractive layout and print easy to read, content clearly organized and graded, plenty of authentic language, good grammar presentation and practice, fluency practice in all four skills, and developing learning strategies of learners to become independent. He used his framework to evaluate a three-book series entitled English Book for the students of senior high school and one pre-university program text book entitled Learning to Read English for PreUniversity Students, in Iran.

Finally Raseks, Eslami, Esmae'li, Ghavamnia, and Rajabi (2010) have also evaluated four ESL text books: Top Notch, Interchange, Headway, and On Your Mark at elementary-level in two phases applying McDonough and Shaw's internal and external evaluation in order to find out which one is a better option for an EFL class. The findings of their study suggested that Top Notch provides learners with more motivating themes and topics in comparison with the other three text books under scrutiny. However, the layout and units are not parallel to what is stated in the table of contents while the other three books exhibit such quality. The dialogues in On Your Marks are shorter and more comprehensive for a beginner learner than the other books, but the book provides reading sections that are rather unchallenging for the intended audience. The New Interchange also presents the key vocabulary under each unit title at the end of the book, in a proper order, however its topics revolve around American culture thus introducing unfamiliar concepts to outsiders. Finally, although Headway contains authentic listening tasks, the pictures portrayed in Headway are black and dull for intended audience.

\section{Studies Based on BRT}

Both Bloom's Taxonomy and BRT are used in different fields for various aims, however; few authors approached these methodologies.

Nobel (2004) combined the revised taxonomy with Gardner's theory of Multiple Intelligences and presented a planning tool for curriculum differentiation. Then teachers used the tool and their progress was documented in using the tool to plan performed units of work during 18 months in two small elementary schools. After that, they reported that improved confidence in their ability after using first the original and then the revised taxonomy. The teachers perceived that their students became more successful than before curriculum differentiation.

Canon and Feinstein (2005) presented how the Revised Taxonomy might be used to structure experiential learning exercises. They said that experiential learning is powerful for creating dynamic knowledge or knowledge that let people use abstractions to manipulate and interact with situations they have never seen before. They also believed that the Revised Taxonomy provides a very operational approach to formulating educational objectives. It addresses them in natural language, using cognitive process to supply the predicate and knowledge structures to supply the direct object of student learning activities. Black and Ellis (2010) presented the development of test questions and tasks based on the 
BRT they offered example questions for each cognitive level. They believed that this approach improved measurement of all the cognitive skill levels needed in today's global financial market place.

Hoeppel (1981) conducted a study in order to categorize questions found in reading skills development books used in Maryland's Community Colleges based on Bloom's Taxonomy. He classified a sample of questions according to Bloom's Taxonomy and the classification showed that $26 \%$ of questions were for knowledge, $74 \%$ were comprehensive, just $0.0035 \%$ was for application and no questions were for analysis, synthesis and evaluation. The findings showed that $99 \%$ of the questions were categorized for two lower levels, knowledge and comprehension.

Amin (2004) conducted a study in Shiraz University about the learning objectives underpinning the general Persian and general English language courses as manifested in text books, exams and instructors' views. She found that those higher levels of cognitive complexity were observed in general Persian course. On the contrary, lower levels of cognitive process were observed in general English courses. Riazi and Mosallanezad (2010) performed a similar study. They focused on the learning objectives based on Bloom's Taxonomy in the content of the high school and pre university English text books taught in Iran. Their findings showed that in four books, lower order cognitive skills were more common than higher order cognitive skills' however, the frequency of higher order cognitive skills increased in Pre University text book.

All the above mentioned studies applied Bloom's Taxonomy, but there are other researchers who based their methodologies on BRT. In Iran, Kazempourfard (2012) refereed to the first study conducted by Lee in 2010 . He determined what levels of thinking were incorporated in Christian publisher's elementary reading text books and if there was a statistically significant difference between the levels of thinking in different text books. He classified two major Christian school publisher (A Beka Book and Bob Jones University Press) based on BRT. He found that the A Beka Book text included 57.6\% lower level questions and 42.4\% higher level questions while the Bob Jones University Press text contained $45.8 \%$ lower level questions and $54.2 \%$ higher level questions.

Kazempourfard evaluated Interchange series (2005) in terms of learning objectives in BRT to see which level of BRT were more emphasized in these text books. The results of her study revealed that Lower Order Thinking Skills, the three low levels in BRT, were the most prevalent learning levels in these books.

The current study tries to evaluate text books not based on evaluation frameworks which have been vastly used by different scholars, rather it tries to evaluate Iranian junior high school English text books in terms of cognitive domain (knowledge and cognitive) of learning objectives as seen in the BRT. This study intends to see whether learning activities in these books encompass an adequately wide range of intellectual and cognitive skills. Thus, the purpose of this study is to analyze Iranian junior high school English text books with regard to their objectives as represented by the content. The analysis took place in relation to cognitive dimension of BRT (the six levels of cognitive dimension and four kinds of knowledge in knowledge dimension of learning objectives in BRT).

Since in the first year of the junior high school curriculum Iranian students are given their first English course, and this is their first experience with learning a foreign language, a special care is needed in setting the objectives and designing activities which offer higher levels of learning. The junior high school English text books are fundamental text books in the EFL curriculum in Iran and consequently it is worth investigating the learning objectives and the cognitive demands of the activities included in them. While this study evaluates the contents and objectives of the mentioned text books, the researcher offers some suggestions for improving the content of the text books which are constantly under improvement. The result of this study can help the curriculum developers to possibly design and develop more effective text books for the future use. This study also seeks to find answers to the following questions:

1. How are the levels of BRT represented in Iranian Junior High School English text books?

2. Which levels of BRT are more common in Iranian Junior High School English text books?

The significance of the present research is in its reference to and reliance on BRT, which has the potential to examine the merits and demerits of intended text book content. The findings can help program designers to revise the book shortcomings or replace with other useful materials with higher standards of learning. Hence, it is necessary to choose and define the relevant criteria by which the merits and demerits of the text books are going to be examined. It can be also beneficial for the English language teachers and educators in Iran to implement the findings of this study. Since the English text books of junior high school have been recently revised, this study can help text book designers to modify and improve English text books for the future use.

\section{Methods}

\subsection{Research Design}

This study is a text book evaluation, a qualitative type of research conduct; however; there has been some quantitative analysis to compute the frequency of each level of learning objectives in BRT. In this type of research method, exercises and tasks are analyzed for the purpose of identifying specified characteristics of the material (Ary, Jacobs, Razavieh \& Serensen, 2006). Researchers used coding scheme (according to the cognitive dimension of BRT, six levels of learning objectives in cognitive domain and four types of knowledge in knowledge dimension of BRT, all parts of junior high School English text books were coded in terms of learning objectives and the frequency of each learning objective calculated for each level and also for the whole levels. Statistical Procedure for Social Sciences version 16 was used for data analysis. 


\subsection{Participants}

This study sought the assistance of three English teachers' viewpoints. These raters were all males and they held B.A. degrees. The reason why they were chosen is that they are actually teaching the intended books to the students in Larestan.

\subsection{Materials}

The materials of the current study were three English text books of the junior high school (junior secondary program) which were evaluated based on B. R.T. In fact the data sources were text books contents. New English text books (student book and work book) of grade seven and grade eight titled English for schools Prospect 1 and Prospect 2 are respectively prescribed for them and the English text book grade three of junior high school entitled Right Path to English which are prescribed by the Iranian ministry of education for the third year students of junior high school. The English text book grade seven was first published and introduced in 2013, and the English text book grade eight was published in 2014, while third year English text book has been used for many years.

\subsection{Instruments}

To conclude the evaluation, the coding scheme of cognitive domain (six levels of learning objectives in cognitive domain and four types of knowledge in knowledge dimension) of the BRT (2001) were used in this study. The purpose of developing the coding scheme was to make it possible for the researcher to use BRT in analyzing the material found in Iranian junior school English text books. The analysis was conducted to detect trends in the cognitive demands inherent in the above mentioned materials. Then; the researcher incorporated the ideas and suggestions of three English teachers in the field of text book evaluation and provided a version of cognitive domain of BRT (2001) for evaluation model of the study. Then SPSS was used to analyze the data.

\subsection{Data organization and analysis}

\subsubsection{Coding scheme}

This study used a coding scheme to codify, classify and analyze the content of the text books which is based on the cognitive domain BRT. The result of coding scheme which is shown in table two presents a two dimensional frameworks identifying both the kind of knowledge to be learned (knowledge dimension which is a combination four types of knowledge) and the kind of learning expected from the student (cognitive processes which is composed of six levels of learning objectives).

The cognitive dimension consists of six levels namely simple recall or recognition of facts, as the lowest, through increasingly more complex and abstract mental levels of evaluation and creation. The categories are labeled as: A) Remember B) Understand C) Apply D) Analyze E) Evaluate F) Create. Moreover, the knowledge dimension comprises four types of knowledge: 1) Factual knowledge 2) Conceptual knowledge 3) Procedural knowledge and 4) Metacognitive knowledge.

Table 2. The coding scheme based on BRT.

\begin{tabular}{|c|c|c|c|c|c|c|}
\hline \multirow{2}{*}{$\begin{array}{l}\text { Knowledge } \\
\text { Dimension }\end{array}$} & \multicolumn{6}{|c|}{ Cognitive Process Dimension } \\
\hline & $\begin{array}{c}\text { Remember } \\
\text { A }\end{array}$ & $\begin{array}{c}\text { Understand } \\
\text { B }\end{array}$ & $\begin{array}{l}\text { Apply } \\
\text { C }\end{array}$ & $\begin{array}{l}\text { Analyze } \\
\text { D }\end{array}$ & $\begin{array}{c}\text { Evaluate } \\
\text { E }\end{array}$ & $\begin{array}{c}\text { Create } \\
\text { F }\end{array}$ \\
\hline 1.Factual Knowledge & A1 & B1 & $\mathrm{C} 1$ & & & \\
\hline $\begin{array}{l}\text { 2.Conceptual } \\
\text { Knowledge }\end{array}$ & A2 & B2 & $\mathrm{C} 2$ & D0 & E0 & F0 \\
\hline $\begin{array}{l}\text { 3.Procedural } \\
\text { Knowledge }\end{array}$ & A3 & B3 & $\mathrm{C} 3$ & & & \\
\hline $\begin{array}{l}\text { 4.Meta-Cognitive } \\
\text { Knowledge }\end{array}$ & A4 & B4 & $\mathrm{C} 4$ & D4 & E4 & F4 \\
\hline
\end{tabular}

In order to clarify how codification was done in this study, an exercise from Student English book grade seven (lesson 3, p. 19) has been codified below. 


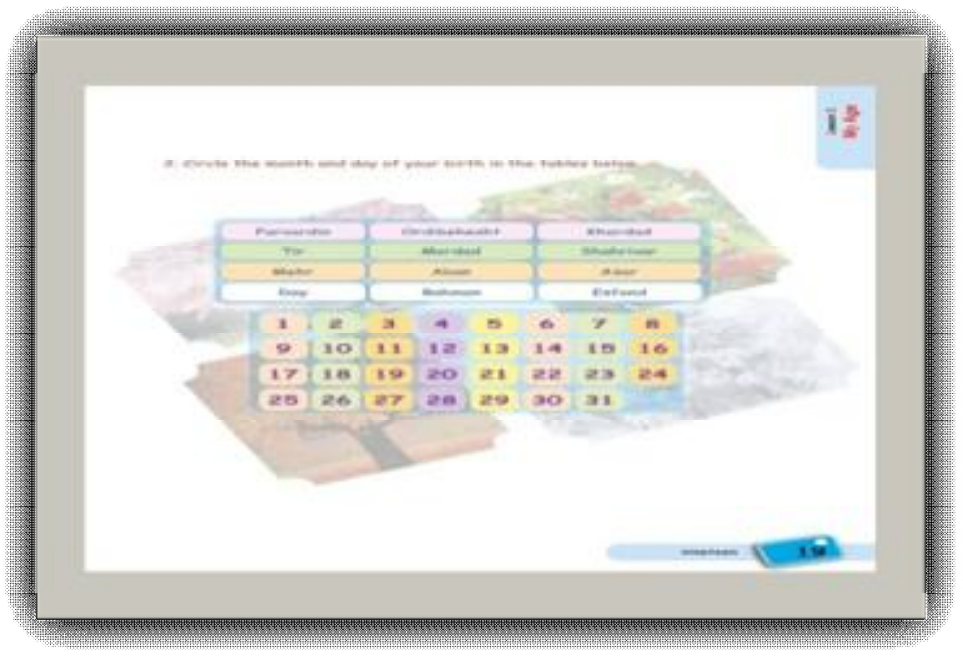

In this exercise, the student should circle the month and day of his/her birth in the table. Taking into consideration the cognitive aspect of human mind, the student has to recall information from his/her memory which is related to the level of Remember and from the aspect of that Knowledge they need specific knowledge to answer the exercise which is related to Factual level. This exercise is labeled as the lowest level in the BRT, namely the level of remember factual knowledge.

According to the coding scheme and since this study was a content analysis two types of reliability are carried out namely: inter_coder and intra_coder. For calculating the reliability three teachers codified one lesson. The result showed that the inter reliability is $77 \%$. For calculating the intra_rater reliability one lesson was selected and after that was coded twice within ten days by the same scorer. The result showed that the degree of consistency is $79 \%$ and this result was used as the intra_coder reliability. The statistical procedures for establishing the reliability was performed by SPSS version 16.

\section{Results and Discussion}

\subsection{The learning objectives in junior high school English text books}

The below table presents the frequencies and percentages of the distribution of the levels of BRT in the Iranian junior high school English text books. The findings of each book are shown in the following table.

Table 3. The learning objectives in English text books

\begin{tabular}{|c|c|c|c|c|c|c|c|c|c|}
\hline \multirow{2}{*}{\multicolumn{2}{|c|}{$\begin{array}{c}\text { Learning objectives } \\
\text { Codes }\end{array}$}} & \multicolumn{4}{|c|}{ Remember } & \multicolumn{4}{|c|}{ Understand } \\
\hline & & A1 & $\mathrm{A} 2$ & A3 & A4 & B1 & B2 & B3 & B4 \\
\hline Student book seven(97) & $\begin{array}{l}\text { Frequency } \\
\text { Percentage }\end{array}$ & $\begin{array}{c}33 \\
34.02 \%\end{array}$ & $\begin{array}{c}2 \\
2.06 \%\end{array}$ & $\begin{array}{c}0 \\
0 \%\end{array}$ & $\begin{array}{c}0 \\
0 \%\end{array}$ & $\begin{array}{c}28 \\
28.86 \%\end{array}$ & $\begin{array}{c}1 \\
1.03 \%\end{array}$ & $\begin{array}{c}0 \\
0 \%\end{array}$ & $\begin{array}{c}0 \\
0 \%\end{array}$ \\
\hline Work book seven $(85)$ & $\begin{array}{l}\text { Frequency } \\
\text { Percentage }\end{array}$ & $\begin{array}{c}38 \\
44.70 \% \\
\end{array}$ & $\begin{array}{c}1 \\
1.17 \% \\
\end{array}$ & $\begin{array}{c}0 \\
0 \% \\
\end{array}$ & $\begin{array}{c}0 \\
0 \% \\
\end{array}$ & $\begin{array}{c}8 \\
9.41 \% \\
\end{array}$ & $\begin{array}{c}6 \\
7.05 \% \\
\end{array}$ & $\begin{array}{c}0 \\
0 \% \\
\end{array}$ & $\begin{array}{c}0 \\
0 \% \\
\end{array}$ \\
\hline Student book eight(74) & $\begin{array}{l}\text { Frequency } \\
\text { Percentage }\end{array}$ & $\begin{array}{c}19 \\
25.67 \% \\
\end{array}$ & $\begin{array}{c}1 \\
1.35 \% \\
\end{array}$ & $\begin{array}{c}0 \\
0 \% \\
\end{array}$ & $\begin{array}{c}0 \\
0 \% \\
\end{array}$ & $\begin{array}{c}15 \\
20.27 \% \\
\end{array}$ & $\begin{array}{c}2 \\
2.70 \% \\
\end{array}$ & $\begin{array}{c}0 \\
0 \% \\
\end{array}$ & $\begin{array}{c}0 \\
0 \% \\
\end{array}$ \\
\hline Work book eight (56) & $\begin{array}{l}\text { Frequency } \\
\text { Percentage }\end{array}$ & $\begin{array}{c}20 \\
35.71 \%\end{array}$ & $\begin{array}{c}2 \\
3.57 \% \\
\end{array}$ & $\begin{array}{c}0 \\
0 \% \\
\end{array}$ & $\begin{array}{c}0 \\
0 \% \\
\end{array}$ & $\begin{array}{c}13 \\
23.21 \% \\
\end{array}$ & $\begin{array}{c}0 \\
0 \% \\
\end{array}$ & $\begin{array}{c}0 \\
0 \% \\
\end{array}$ & $\begin{array}{c}0 \\
0 \% \\
\end{array}$ \\
\hline Book three (127) & $\begin{array}{l}\text { Frequency } \\
\text { Percentage }\end{array}$ & $\begin{array}{c}21 \\
16.53 \% \\
\end{array}$ & $\begin{array}{c}0 \\
0 \% \\
\end{array}$ & $\begin{array}{c}0 \\
0 \% \\
\end{array}$ & $\begin{array}{c}0 \\
0 \% \\
\end{array}$ & $\begin{array}{c}18 \\
14.17 \% \\
\end{array}$ & $\begin{array}{c}0 \\
0 \% \\
\end{array}$ & $\begin{array}{c}0 \\
0 \% \\
\end{array}$ & $\begin{array}{c}0 \\
0 \% \\
\end{array}$ \\
\hline average & Percentage & $31.32 \%$ & $1.63 \%$ & $0 \%$ & $0 \%$ & $19.18 \%$ & $2.15 \%$ & $0 \%$ & $0 \%$ \\
\hline
\end{tabular}

\begin{tabular}{|c|c|c|c|c|c|c|c|}
\hline \multirow{2}{*}{\multicolumn{2}{|c|}{$\frac{\text { Learning objectives }}{\text { Codes }}$}} & \multicolumn{4}{|c|}{ Apply } & \multicolumn{2}{|c|}{ Analyze } \\
\hline & & $\mathrm{C} 1$ & $\mathrm{C} 2$ & $\mathrm{C} 3$ & $\mathrm{C} 4$ & D0 & D4 \\
\hline Student book seven(97) & $\begin{array}{l}\text { Frequency } \\
\text { percentage }\end{array}$ & $\begin{array}{c}11 \\
11.34 \%\end{array}$ & $\begin{array}{c}22 \\
22.11 \%\end{array}$ & $\begin{array}{c}0 \\
0 \%\end{array}$ & $\begin{array}{c}0 \\
0 \%\end{array}$ & $\begin{array}{c}0 \\
0 \%\end{array}$ & $\begin{array}{c}0 \\
0 \% \\
\end{array}$ \\
\hline Work book seven( 85$)$ & $\begin{array}{l}\text { Frequency } \\
\text { percentage }\end{array}$ & $\begin{array}{c}24 \\
28.23 \%\end{array}$ & $\begin{array}{c}8 \\
9.41 \%\end{array}$ & $\begin{array}{c}0 \\
0 \%\end{array}$ & $\begin{array}{c}0 \\
0 \%\end{array}$ & $\begin{array}{c}0 \\
0 \%\end{array}$ & $\begin{array}{c}0 \\
0 \%\end{array}$ \\
\hline Student book eight(74) & $\begin{array}{l}\text { Frequency } \\
\text { Percentage }\end{array}$ & $\begin{array}{c}14 \\
18.91 \%\end{array}$ & $\begin{array}{c}23 \\
31.08 \%\end{array}$ & $\begin{array}{c}0 \\
0 \%\end{array}$ & $\begin{array}{c}0 \\
0 \%\end{array}$ & $\begin{array}{c}0 \\
0 \%\end{array}$ & $\begin{array}{c}0 \\
0 \%\end{array}$ \\
\hline
\end{tabular}




\begin{tabular}{|c|c|c|c|c|c|c|c|}
\hline & Frequency & 15 & 1 & 0 & 0 & 5 & 0 \\
Work book eight (56) & percentage & 26.78 & $1.78 \%$ & $0 \%$ & $0 \%$ & $8.92 \%$ & $0 \%$ \\
\hline & Frequency & 17 & 71 & 0 & 0 & 0 & 0 \\
Book three (127) & percentage & $13.38 \%$ & $55.90 \%$ & $0 \%$ & $0 \%$ & $0 \%$ & $0 \%$ \\
\hline Average & $\begin{array}{l}\text { Frequency } \\
\text { percentage }\end{array}$ & $19.72 \%$ & $24.05 \%$ & $0 \%$ & $0 \%$ & $1.78 \%$ & $0 \%$ \\
\hline
\end{tabular}

\begin{tabular}{|c|c|c|c|c|c|}
\hline \multicolumn{2}{|c|}{ Learning objectives } & \multicolumn{2}{c|}{ Evaluate } & \multicolumn{2}{c|}{ Create } \\
\hline \multicolumn{2}{|c|}{ Codes } & E0 & E4 & F0 & F4 \\
\hline Student book seven(97) & Frequency & 0 & 0 & 0 & 0 \\
& percentage & $0 \%$ & $0 \%$ & $0 \%$ & $0 \%$ \\
\hline Work book seven(85) & Frequency & 0 & 0 & 0 & 0 \\
& percentage & $0 \%$ & $0 \%$ & $0 \%$ & $0 \%$ \\
\hline Student book eight(74) & Frequency & 0 & 0 & 0 & 0 \\
& percentage & $0 \%$ & $0 \%$ & $0 \%$ & $0 \%$ \\
\hline Work book eight (56) & Frequency & 0 & 0 & 0 & 0 \\
& percentage & $0 \%$ & $0 \%$ & $0 \%$ & $0 \%$ \\
\hline Book three (127) & Frequency & 0 & 0 & 0 & 0 \\
& percentage & $0 \%$ & $0 \%$ & $0 \%$ & $0 \%$ \\
\hline Average & Frequency & 0 & 0 & 0 & 0 \\
& percentage & $0 \%$ & $0 \%$ & $0 \%$ & $0 \%$ \\
\hline
\end{tabular}

In the first book, student book for grade seven, the most frequent learning level is A1 (Remember factual knowledge) with the frequency of $34.02 \%$, the next most frequent code as follow: B1 (Understand factual knowledge) with the frequency of $28.86 \%$, the next is C2 (Apply conceptual knowledge) with the percentage of $22.11 \%$, and C1 (Apply factual knowledge) with percentage $11.34 \%$, A2 (Remember conceptual knowledge) with percentage $2.06 \%$ and B2 (Understand conceptual knowledge) with the percentage of 1.03\% while, A3 (Remember procedural knowledge), A4 (Remember metacognitive knowledge), B3 (Understand procedural knowledge), B4 (Understand metacognitive knowledge), C3 (Apply procedural knowledge), C4 (Apply metacognitive knowledge), D0 (Analyze using facts, concepts, principles and procedures), D4 (Analyze metacognitive knowledge), E0 (Evaluate using facts, concepts, principles and procedures), E4 (Evaluate metacognitive knowledge), F0 (Create using facts, concepts, principles and procedures) and F4 (Create metacognitive knowledge) are absent in the coded data. Figure 2 represents the findings of student book grade seven based on BRT.

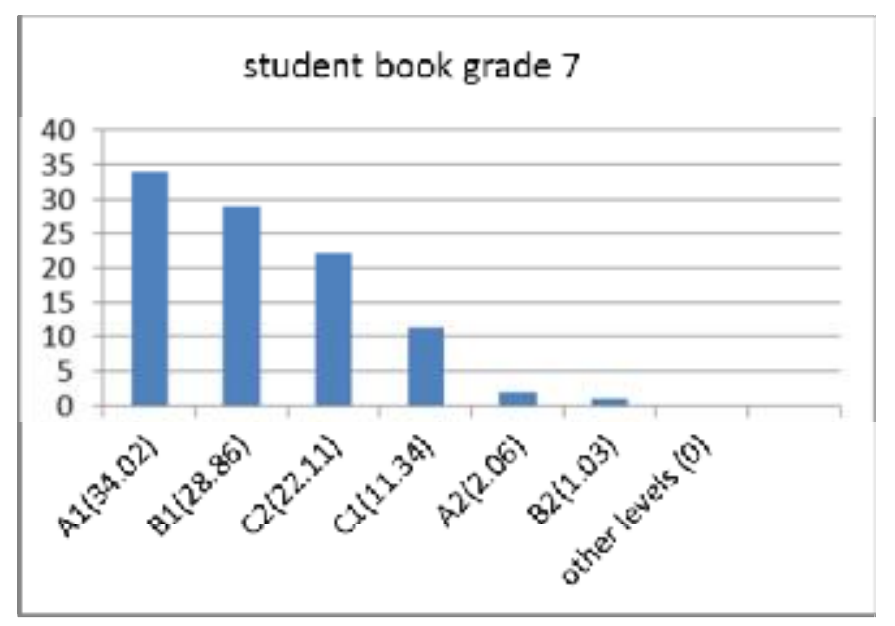

Figure 2. Learning levels (BRT) in student book grade seven

The second book is work book grade seven which A1 (Remember factual knowledge) with the frequency of $44.70 \%$, is the most frequent code, the next one is B1 (Understand factual knowledge) with the frequency of $28.86 \%$ and $\mathrm{C} 1$ (Apply factual knowledge) with the percentage of 28.23\% and C2 (Apply conceptual knowledge) with frequency of $22.11 \%$ and B2 (Understand conceptual knowledge) with frequency of 1.03, while A3 (Remember procedural knowledge), A4 (Remember metacognitive knowledge), B3 (Understand procedural knowledge), B4 (Understand metacognitive knowledge), C3 (Apply procedural knowledge), C4 (Apply metacognitive knowledge), D0 (Analyze using facts, concepts, principles and procedures), D4 (Analyze metacognitive knowledge), E0 (Evaluate using facts, concepts, principles and procedures), E4 (Evaluate metacognitive knowledge), F0 (Create using facts, concepts, principles and procedures) and F4 (Create metacognitive knowledge) are absent in the coded data. Figure 3 shows these findings. 


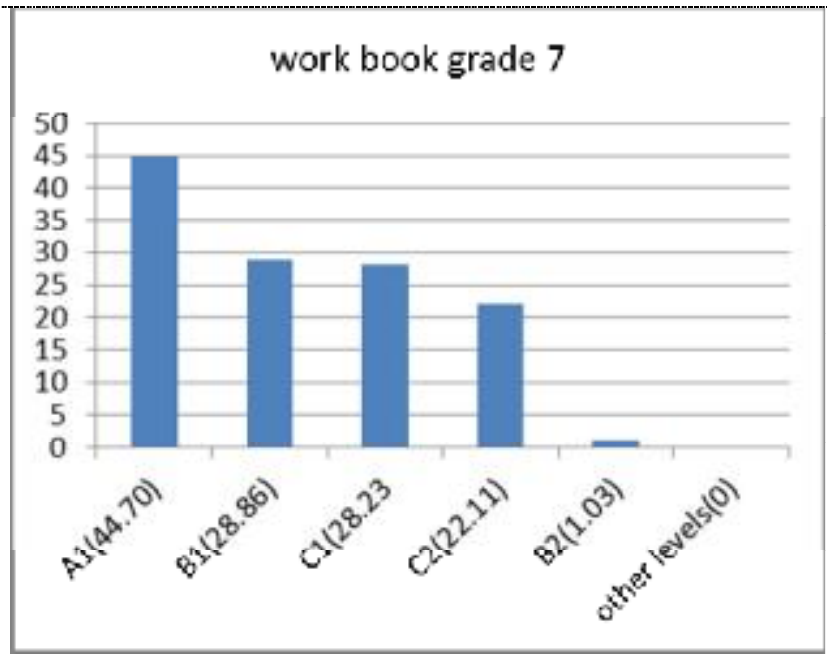

Figure 3. Learning levels (BRT) in work book grade seven

The third book is student book grade eight which the most common frequent learning level is C2 (Apply conceptual knowledge) with the frequency of $31.08 \%$ and the next common learning level is A1 (Remember factual knowledge) with the frequency of $25.67 \%$, B1 (Understand factual knowledge) with the frequency of 20.27\%, B2 (Understand conceptual knowledge) with percentage of $2.70 \%$ and A2 (Remember conceptual knowledge) has the percentage of $1.35 \%$ whereas, A3 (Remember procedural knowledge), A4 (Remember metacognitive knowledge), B3 (Understand procedural knowledge), B4 (Understand metacognitive knowledge), C3 (Apply procedural knowledge), C4 (Apply metacognitive knowledge), D0 (Analyze using facts, concepts, principles and procedures), D4 (Analyze metacognitive knowledge), E0 (Evaluate using facts, concepts, principles and procedures), E4 (Evaluate metacognitive knowledge), F0 (Create using facts, concepts, principles and procedures) and F4 (Create metacognitive knowledge) are absent in the coded data. Figure 4 shows these findings.

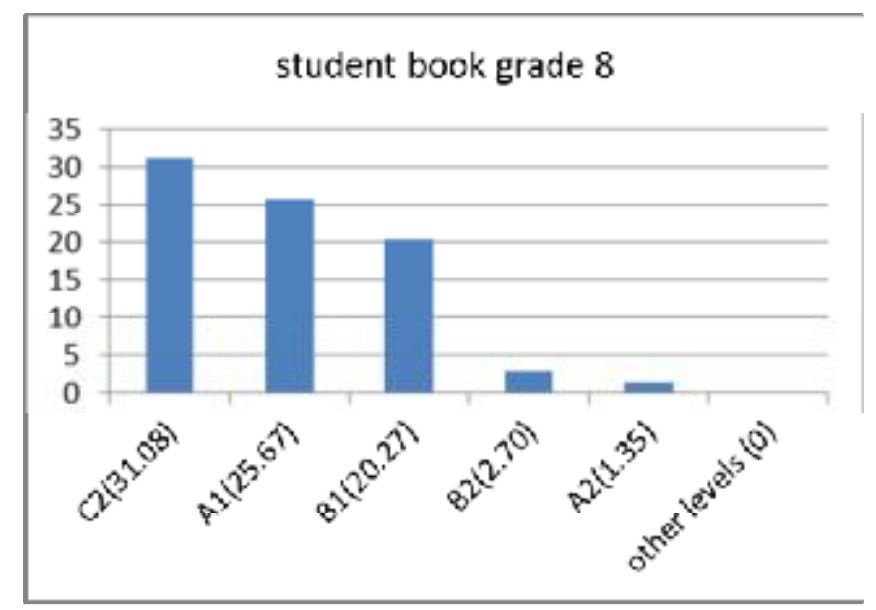

Figure 4. The learning levels (BRT) in student book grade eight

In work book grade eight, the most common learning level is A1 (Remember factual knowledge) with the frequency of $35.71 \%$, the next one is $\mathrm{C} 1$ (Apply factual knowledge) with the frequency of 25\%, B1 (Understand factual knowledge) with the percentage of $23.21 \%$, D0 (Analyze using facts, concepts, principles and procedures) with the frequency of 8.97, A2 (Remember conceptual knowledge) with frequency of 3.57\% and C2 (Apply conceptual knowledge) with frequency of $1.71 \%$ whereas A3 (Remember procedural knowledge), A4 (Remember metacognitive knowledge), B3 (Understand procedural knowledge), B4 (Understand metacognitive knowledge), C3 (Apply procedural knowledge), C4 (Apply metacognitive knowledge), D4 (Analyze metacognitive knowledge), E0 (Evaluate using facts, concepts, principles and procedures), E4 (Evaluate metacognitive knowledge), F0 (Create using facts, concepts, principles and procedures) and F4 (Create metacognitive knowledge) are absent in the coded data. Figure 5 shows these findings. 


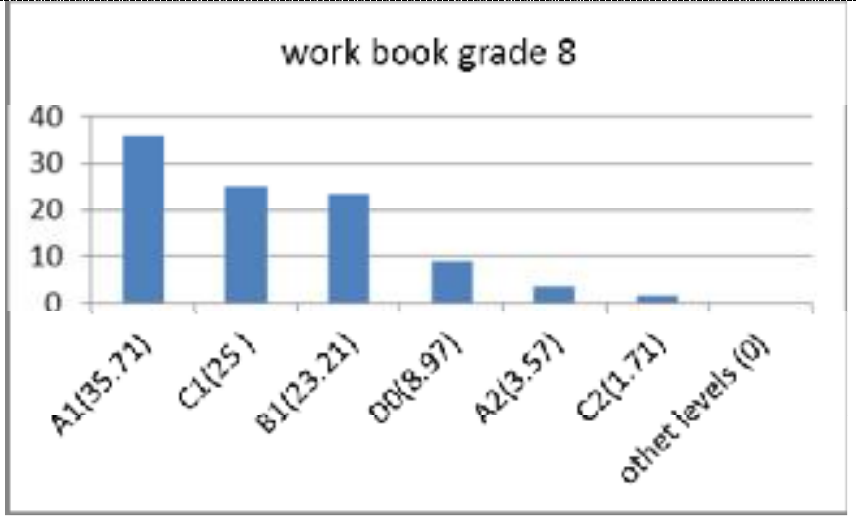

Figure 5. The learning levels (BRT) in work book grade eight

Finally, in English book grade three, the most common learning level is C2 (Apply conceptual knowledge) with the frequency of $55.90 \%$ and the next one is A1 (Remember factual knowledge ) with frequency of $16.53 \%$, B1 ( Understand factual knowledge ) with the frequency of $14.17 \%, \mathrm{C} 1$ (Apply factual knowledge) with frequency of $13.38 \%$ and A2 (Remember conceptual knowledge ), A3 (Remember procedural knowledge), A4 (Remember metacognitive knowledge), B2 (Understand conceptual knowledge), B3 (Understand procedural knowledge), B4 (Understand metacognitive knowledge), C3 (Apply procedural knowledge), C4 (Apply metacognitive knowledge), D0 (Analyze using facts, concepts, principles and procedures), D4 (Analyze metacognitive knowledge), E0 (Evaluate using facts, concepts, principles and procedures), E4 (Evaluate metacognitive knowledge), F0 (Create using facts, concepts, principles and procedures) and F4 (Create metacognitive knowledge) are absent in the coded data. Figure 6 shows these findings.

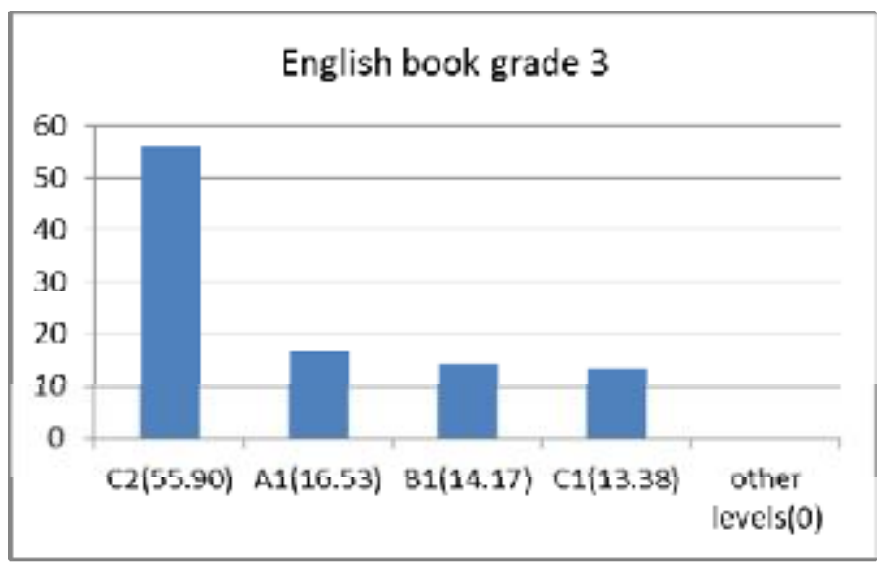

Figure 6. learning levels (BRT) in English book grade three

As can be seen in the above figures, the lower learning levels are the most common cognitive skills in the junior high school English text books based on BRT, therefore it can be mentioned that three categories at the bottom of the taxonomy, Remember, Understand and Apply are the most common skills in theses text books. Generally speaking, among these learning levels in cognitive (cognitive and knowledge) domain of BRT, A1 (Remember factual knowledge) that is the first level of BRT with a percentage of 31.32 is the most common code in junior high school English text books and the next code is C2 (Apply conceptual knowledge) with a percentage of 24.05 and C1 (Apply factual knowledge) with frequent of 19.72, B1 (Understand factual knowledge) with a percentage of 19.18 , B2 (Understand conceptual knowledge) with a percentage of 2.15, D0 (Analyze using facts, concepts, principles and procedures) with a percentage of 1.78 and the last level is A2 (Remember conceptual knowledge) with a percentage of 1.63 and other levels such as A3, A4, B3, B4 , C3 , C4, D4, E0, E4, F0, F4 are absent in these text books. By dividing BRT into lower and higher cognitive skills, the findings reveal that lower cognitive skills were the most frequent in junior high school English books. The most learning objectives of cognitive skills in Iranian junior high school English text books are presented in the following table (4) and figure (7). 


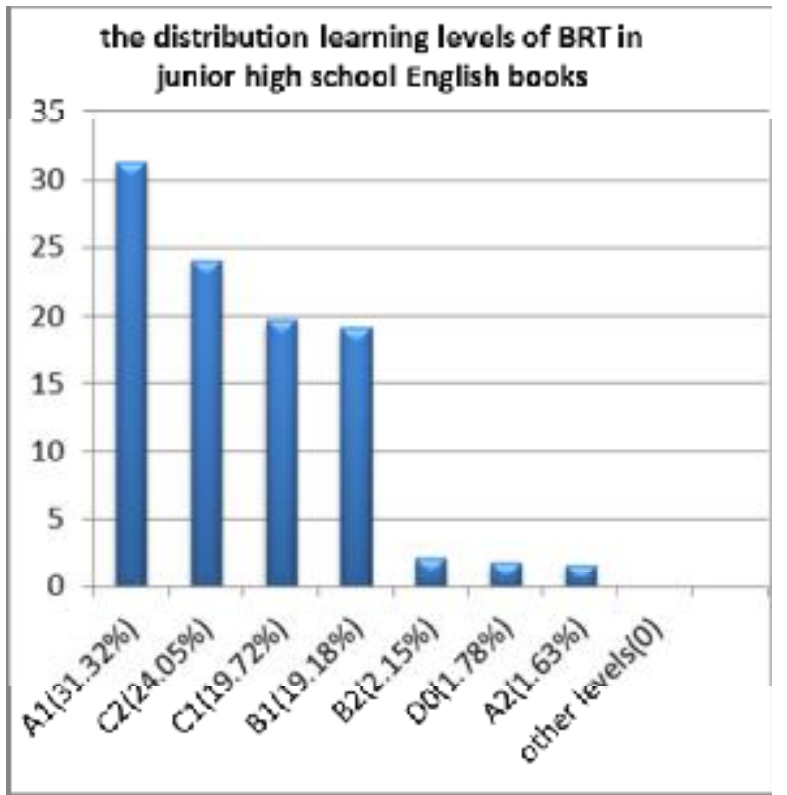

Table 4. The distribution of learning levels of BRT in junior high school English books

Figure 7. The overall distribution of learning levels BRT in junior high school English books.

\begin{tabular}{|c|c|}
\hline Cognitive skills & percentage \\
\hline 1.A1 & $\mathbf{3 1 . 3 2}$ \\
2.C2 & $\mathbf{2 4 . 0 5}$ \\
3.C1 & $\mathbf{1 9 . 7 2}$ \\
4.B1 & $\mathbf{1 9 . 1 8}$ \\
5.B2 & $\mathbf{2 . 1 5}$ \\
6.D0 & $\mathbf{1 . 7 8}$ \\
7.A2 & $\mathbf{1 . 6 3}$ \\
8.other levels & $\mathbf{0}$ \\
& \\
& \\
& \\
& \\
& \\
& \\
\end{tabular}

\subsection{Discussion}

The findings of the current study are consistent with those of Mosalanejad (2010) and Kazempourfard (2012) who respectively examined the senior high school and pre university text books and Interchange books based on Blooms taxonomy and Blooms revised taxonomy. Mosalanejad (2010) studied senior high school and pre university English text books based on Blooms taxonomy and the results of her study indicated that in all grades lower-order cognitive skills were more prevalent than higher order ones. In agreement with Mosalanejad, Kazempourfard (2012) evaluated Interchange books series in terms of BRT and she revealed that Lower Order Thinking Skills (LOTS), the three low levels in BRT, are the most prevalent learning levels in these books. The results of this study are in keeping with previous observational studies which with reference to the above data, the most common code in student book and work book grade seven and of course in other books is A1 (remember factual knowledge) with frequency of 34.2, and 44.70. Based on this finding, it can be inferred that the authors paid special attention to this level, because students are beginner learners of English and they don't have any experience of learning English and their proficiency level prevent them from accessing higher levels of cognitive levels. It means that students at this level can perform simple cognitive activities of remembering information and they cannot solve complex tasks such as, analyzing, evaluating, and creating. This could also be a result of the fact that in the educational system of Iran, the major emphasis is on acquiring knowledge in the form of rote learning and memorization, rather than constructing it through higher-levels of cognitive skills such as analyzing, evaluating and creating. It should be mentioned that in student book and work book seven and work book eight, A1 is the most frequent code but the main point is that the frequency of this code decreased in next grades, for example, A1 in student book and work book grade seven is 34.2 and 44.70; but in student book and work book grade eight decreases to 25.67 and 35.71 and in book grade three the frequency of A1 decrease to 16.53 it could mean that authors of the books paid less attention to this lower level and preferred to pay more attention to higher and more complex levels and exercises. The second most common code is C2 (apply conceptual knowledge) with a whole average of 24.05, this code is common between student book grade eight and English book grade three, with a frequency of 31.8 and 55.90. In these exercises the students were required to apply a model (grammar structures). The findings of this study indicate that the third most common code in Junior High School English text books is not from higher order cognitive skills; but it is C1 (apply factual knowledge) with a whole percentage of 19.72, which is the most common code in work book grade seven (28.23) and work book grade eight with a frequency of 26.78. So as seen the third most frequent code is again among the lower levels of BRT. Generally, the findings reveal that the average percentage of lower levels is more than higher levels. D0 (analyze using facts, concepts, principles and procedures) with a frequency of 1.78 was the only higher level which was used in these books. This means that lower levels of BRT are the most usual learning levels in Junior High Schools English text books.

Another result that could be obtained from this study is that; although, the frequency of lower levels were more than higher levels, their distribution were not equals. The frequency of distribution of learning levels in these books show that these learning levels were not used consistently in Junior High School English text books. The final finding is the absence of A3 (remember procedural knowledge), A4 (remember metacognitive knowledge), B3 (understand procedural knowledge), B4 (understand metacognitive knowledge ), C3 (apply procedural knowledge), C4 (apply metacognitive knowledge), D4 (analyze metacognitive knowledge), E0 (evaluate using facts, concepts, principles and procedures), E4 (evaluate metacognitive knowledge), F0 (create using facts, concepts, principles and procedures) and 
F4 (create metacognitive knowledge). As mentioned earlier the possible reason is that the authors paid attention to the fact that students are beginner learners of English, consequently they can't perform complex tasks; so, most of the higher learning levels are absent in these books except D0 which was used in work book grade eight. It may be an indicator of students' progress toward higher grades and are facing with more complex activities and higher learning objectives of BRT. The authors possibly supposed that learners with higher levels of language proficiency must be able to do complex cognitive activities of learning levels in Junior High School English text books; so, it is expected that in English book Prospect 3 and English book Vision for students senior high school the percentage of higher levels of BRT will be more than Prospect 1and 2.

\section{Conclusion}

The research questions are answered in this part:

1. How are the levels of BRT presented in the junior high school English text books?

It was observed that the books follow the principles proposed by BRT to some extent. In the student book and work book grade seven, A1 the lowest level in BRT is the most frequent learning level with a percentage of 34.2 and 44.70. The next most frequent learning level was B2 with a percentage of 28.86 .

In the student book grade eight the most common level is C2 with frequency of 31.08 and the next frequent level is A1with frequency of 25.67. In the work book grade eight the most frequent learning level is A1 with a percentage of 35.71. The next is $\mathrm{C} 1$ with frequency of 25 and finally in the English book grade three the most frequent learning levels were: C2, A1 with a percentage of 55.90 and 16.53 respectively. According to table (4) the most overall distribution learning levels in Iranian junior high school English text books were A1 (31.32), C2 (24.05), C1 ( 19.73), B1 (19.18), B2 (2.15), D0 (1.78), and A2 (1.63), therefore, it could be witnessed that the lower learning levels of BRT were most prominent codes in junior high school English text books. The researchers found that A3, A4, B3. B4, C3, C4, D4, E0, E4, F0 and F4 were absent in these English text books. Figure 7 presents the overall distribution of learning levels in junior high school English books.

2. Which levels of BRT are more common in Iranian junior high school English text books?

The overall findings of this study demonstrate that the most frequent learning objectives pursued in the junior high school English text books in Iran are lower-order learning levels of BRT, that is, A1 (Remember factual knowledge), C2 (Apply Conceptual knowledge) and C1 (Apply factual knowledge) .

\subsection{Pedagogical Implications}

This study suggests some pedagogical as follow:

1. As most of the exercises in junior high schools are based on lower learning levels of BRT and this prevents student from accessing to higher learning levels, teachers can improve this by using exercises from other sources.

2. In order for the teachers to promote the levels of their students' knowledge to higher levels such as analysis, evaluation, and creation, they can use other materials such as: films, songs etc. which may ignite deeper thinking and effort on the part of their students.

\subsection{Recommendations for Further Research}

1. Another study can be conducted to see the representation of BRT in the prospect 3 and English books vision for student's senior high school.

2. Also a questionnaire could be developed based on the BRT to learn the ideas of teachers and students pertaining to new version of English books.

3. Affective and psychomotor domains of BRT could be studied in the junior high school English text books.

\section{References}

Amalsaleh, E. (2004).The representation of social actors in the EFL text books in Iran (Unpublished doctoral dissertation). Shiraz University, Shiraz.

Amin, A. (2004). Learning objectives in university Persian \& English general language courses in terms of Bloom's taxonomy (Unpublished master's thesis), Shiraz University, Shiraz.

Anderson, L. W., \& Krathwohl, D. R. (Eds.). (2001). A taxonomy for learning, teaching and assessing: A revision of Bloom's Taxonomy of educational objectives: Complete edition, New York: Longman.

Ary, D., Jacobs, L.C. Razavieh, A., \& Sorensen, C. (2006). Introduction to research in education (7th Ed.). Orlando, FL: Harcourt Brace College Publishers.

Black, S.M. \& Ellis, R.B. (2010). Evaluating the level of critical thinking in introductory investment courses. Retrieved from http:// www. The free library. com

Canon, H.M. \& Feinstein, A.H. (2005). Bloom beyond Bloom: Using the revised taxonomy to develop experiential learning strategies. Developments in Business Simulations and Experiential Learning 32 (3), 48-356.

Chang, J. (2006). Globalization and English in Chinese higher education. World English's 25(8), 513 _525.

Cunningsworth, A. (1995). Choosing your course book. Oxford, UK: Heinemann. 
Ellis, R. (1997). The empirical evaluation of language teaching materials. ELT Journal, 51(1), 36-42.

Hutchinson, T. \& Torres. (1994). The text book as agent of change. ELT Journal. 48 (4), 315- 328.

Jahangard, A. (2008). Evaluation of EFL materials taught at Iranian public high schools. The Asian EFL Journal, 9(2), $130-150$.

Kazempourfard, E. (2012). On the representation of Blooms revised taxonomy in interchange course books. JTL journal, 4 (1).

Khajavi, Y., \& Abbasian, R. (2011). English language teaching, national identity and globalization in Iran: The case of public schools. International Journal of Humanities and Social Science. 1 181-186. Retrieved from: www.sid.ir

Noble, T. (2004). Integrating the revised Bloom's taxonomy with multiple intelligences: A planning tool for curriculum differentiation. Teachers College Record, 106 (1), 193-211.

Oregon State University. (2004). OSU extended campus: Course development: Instructional design -the taxonomy table. Retrieved April 3, 2005 from http://oregonstate.edu/ instruct/ coursedev/ models/ id/taxonomy/

Oz-teacher Net. (2001). Oz-Teacher Net: Teachers helping teachers: Revised Bloom's Taxonomy. Retrieved March 19 , 2005 from http://www.rite.ed.qut.edu.au

Raseks, A. E., Esmae'li, S., Ghavamnia, M., \&Rajabi, S. (2010). Don't judge a text book by its cover: Text book evaluation in the EFL settings. The Journal of International Social Research, 3(14), 448-461

Riazi, A.M. \&Mossalanejad, N. (2010).Evaluation of learning objectives in Iranian high-school and pre-university English text books using Bloom's taxonomy. The Electronic Journal for English as a Second Language. 13(5), 1-16.

Yarmohammadi, L. (2002). The evaluation of pre-university text books. The Newsletter of the Iranian Academy of Science, 18(7), 70-87. 